\title{
The Impact of the PSR Rural Insurance Program on the Agricultural Productivity in the Matopiba Region of Brazil
}

\author{
Francisco José da Silva Tabosa ${ }^{1}$, Pablo Urano de Carvalho Castelar ${ }^{2}$, José Eustáquio Ribeiro Vieira Filho ${ }^{3}$, \\ Domingos Isaías Maia Amorim ${ }^{4} \&$ Maria Josiell Nascimento Da Silva ${ }^{4}$ \\ ${ }^{1}$ Agricultural Economics Department, Federal University of Ceará (UFC), Brazil \\ ${ }^{2}$ Finance Course, Federal University of Ceará, Brazil \\ ${ }^{3}$ Institute of Applied Economic Research (IPEA) and Brazilian Ministry of Agriculture, Livestock and Supply \\ (MAPA), Brazil \\ ${ }^{4}$ ESALQ-USP, University of São Paulo (USP), Brazil \\ Correspondence: Gamel Abdul-Nasser Salifu, Professor, Finance Course, Federal University of Ceará, Brazil.
}

Received: September 17, 2020

Accepted: February 5, 2021

Online Published: June 1, 2021

doi:10.5430/ijba.v12n4p1

URL: https://doi.org/10.5430/ijba.v12n4p1

\begin{abstract}
The present work aims to analyze the impact of a government subsidy program of rural insurance in Brazil, (called the Programa de Subvenção ao Prêmio de Seguro Rural - PSR), on the productivity of insured producers in the MATOPIBA region of the country, which encompasses four Brazilian states, Maranhão, Tocantins, Piauí and Bahia, between the years 2008 to 2019. For this, municipalities were selected that had at least one insured producer throughout the analyzed period. The variables used were the number of producers, the number of insurance policies, the planted area, the productivity obtained and the insured financial amount of the producers. The methodological procedure was based on Auto-regressive Vectors (VAR) for panel data. The results showed a concentration, of all the variables used in the research, in the state of Bahia, mainly in the municipalities of Formosa do Rio Preto and São Desidério, whose main economic activity is soy production. It was also found that the impulse response functions on productivity obtained through a shock in the other variables, except the planted area variable, the others showed positive initial (short-term) responses until the second year. The average time for responses to smooth over time occurs from the sixth year onwards.
\end{abstract}

Keywords: subsidy program for the rural insurance premium, Brazil, MATOPIBA region, auto-regressive vector model for panel data

\section{JEL: Q18; Q19}

\section{Introduction}

The Brazilian agricultural sector has grown since the 1970s. According to Gasques et al. (2012), Medeiros (2013) and Silva et al. (2014), from 1970 to 2006, agricultural production increased more than the growth of the total area used for agriculture, which generated a strong productivity growth. Yield increased over time by a proportion of 10, while the harvested area only doubled (Note 1). This performance was extraordinary, given the presence of several risks in the production process.

The production of plant and animal organisms, the dependence on climatic conditions and the high price volatility create uncertainties in the productive process of agricultural activity. The management of risks inherent to production is essential to minimize losses and reduce losses related to adverse events. The main risk factors are due to climatic problems, incidence of pests, fires and even price volatility, which can be associated with market failures, such as imperfect competition, scarcity of credit, fluctuations in demand and technological aspects (Medeiros, 2013; Silva et al., 2014). These factors are capable of reducing investment in the sector, causing the displacement of financial resources to other less risky activities.

In this sense, agricultural insurance is able to create stability in the business environment, in order to reduce the risk of adverse events and to avoid fluctuations around productive investment. (Note 2) (Ozaki, 2007, 2010). The producer to be insured seeks a financial intermediary that makes minimum production guarantee parameters feasible in the event of 
adverse events, which may cause economic and financial losses. In some cases, the financial system itself adjusts, offering different types of insurance; however, given the characteristics of agricultural production, it is necessary to create incentives that link the producer and the financial institutions.

In order to make insurance protection more accessible to rural producers in Brazil, the Rural Insurance Premium Subsidy Program (PSR) in 2005 was created by the federal government. This policy sought to subsidize part of the cost of agricultural insurance to producers and, simultaneously, it contributed to bring together policyholders and financial agents in the process. In some cases, the purchase of agricultural insurance may have a subsidy ranging from $35 \%$ to $45 \%$ of the amount insured in the policy, varying by the type of cultivation and livestock activity, with different levels of coverage.

Although the subsidy is intended for rural producers, the grant request is made by the financial intermediary, or insurance company, which submits the contracted insurance policies to the Ministry of Agriculture, Livestock and Supply (Ministério da Agricultura, Pecuária e Abastecimento - MAPA). After evaluation the registration of the producer, if there are no restrictions and, at the same time, there are resources available in the budget, technicians from the ministry grant the benefit to settle part of the premium specified in the contracts. The main objective of rural insurance is to maintain the stability of the investment, on the one hand, and the competitiveness of the sector, even in conditions of capital loss or crop failure, on the other.

According to statistical information from MAPA (2017), there is a concentration in the acquisition of insurance, both in terms of product, and depending on the region. For instance, about $44 \%$ of insurance policies were concentrated on soy production, with almost $60 \%$ of total insurance policies in Brazil for all products concentrated in two states only, Paraná and Rio Grande do Sul. Tabosa and Vieira Filho (2018) observed that the North and Northeast regions of the country have the lowest percentages of producers and insurance policies contracted in Brazil (Note 3). Most of these insurance policies are linked to producers residing in the MATOPIBA region. This region represents $8.6 \%$ of the national territory, totaling 337 municipalities. Thus, it is important and worthwhile to assess the impact of the referred program on the productivity of insured producers in the MATOPIBA region of Brazil.

Thus, the present research seeks to study the impact of the PSR program on the productivity of insured producers. For this, state information on the number of producers, number of insurance policies, planted area, insured amount and productivity of the insured will be used between the years 2008 and 2019, and with the Autoregressive Vectors (VAR) method for panel data. The panel VAR model was chosen for, as mentioned by Canova and Cicarelli (2013), these models are built with the same logic of standard VARs but, by adding a cross sectional dimension, this method allows for a more thorough analysis of the impact of economic policies. For example, Traoré (2018) uses a Panel VAR model to analyze if government spending in sub-Saharan Africa leads to less inequality and more economic growth. Ying and Chang (2019), on the other hand, analyze how government expenditure on health, through the National Heath Insurance in Taiwan, impacts the financial spending on health of Taiwanese individuals.

The objective of this work, therefore, is to analyze whether the PSR program, through the number of insured producers, the number of policies contracted, the amount insured and the planted area, has any impact on the productivity of the insured producers. That is, if these producers, when purchasing a PSR policy, are feeling safer to expand their production.

\section{The Matopiba Region of Brazil}

Considered to be the great national agricultural frontier in current times, the MATOPIBA region of Brazil comprises the Cerrado biome, which is a tropical savanna ecoregion, of the states of Maranhão, Tocantins, Piauí and Bahia, and accounts for a large part of the Brazilian production of grains and fibers. The area, until recently considered without a strong tradition in agriculture, has attracted attention due to its ever-increasing productivity (BUAINAIN et al, 2017).

In 2010, the total population of MATOPIBA was 5.9 million people (3.1\% of the Brazilian population). In 2012, the area used for agriculture represented 24.5 million hectares. In 2013, the gross domestic product at market prices in the MATOPIBA region was estimated at $\mathrm{R} \$ 73$ billion, 1.4\% of the Brazilian GDP (IBGE, 2016; BUAINAIN, et al., 2017).

The economy and the structures present at the MATOPIBA region, driven by the dynamism of agriculture in the Cerrado areas is the largest concentration in the generation of income in some municipalities and the consequent increase in inequality within the region (GASQUES, 2016). This movement, in a way, will have an impact on the evolution of institutional infrastructure, improving the human development indexes of the region.

Therefore, the MATOPIBA region is concentrated in temporary crops, since the productive system adopted in the occupation of MATOPIBA's agricultural areas is supported by a new pattern of agricultural accumulation 
(BUAINAIN et al., 2014; BUAINAIN and GARCIA, 2015). In addition, permanent crops have little relevance in the agricultural system installed in the region.

The main product in the MATOPIBA region is soybeans, whose planted area increased by $600 \%$ in the period, reaching 2.4 million hectares in 2010-2012 (BUAINAIN et al, 2017). The expansion of soy contributed to reducing its degree of spatial concentration; since in 1990-1992, the ten largest municipalities in area planted with soybeans concentrated 93\% of the regional area dedicated to this cultivation, and, in the 2010-2012 three-year period, accounted for 59\% of the area planted with soybeans (BUAINAIN et al., 2017). The cultivation of soy has moved to the states of Maranhão and Piauí, and to a lesser extent to Tocantins, on the border with these states.

Another product featured in the region is cotton. Cotton cultivation was concentrated in ten municipalities, eight of them in the state of Bahia and two in Maranhão, which accounted for $90 \%$ of the planted area. The expansion accentuated the concentration of this crop, since ten municipalities with cotton planted account for $93 \%$ of the regional planted area, seven of them from Bahia, two from Maranhão and one from Piauí. Only 32 municipalities in MATOPIBA registered an area planted with this crop (IBGE, 2016), reinforcing the concentration of cultivation in 2010-2012. In the case of soybeans, 137 municipalities registered a planted area (IBGE, 2020).

In the following section, we briefly summarize some of the main findings in the academic literature which have analyzed rural insurance programs.

\section{Literature Review}

Rosenzweig and Binswanger (1993) found that smaller and poorer farmers in a semi-arid region of India sacrificed $27 \%$ of the expected income to reduce the risk. Farmers are less willing to invest in more profitable technologies and land improvements when they are in riskier environments, leading to additional sacrifices for middle income.

Risks are also a problem for financial institutions and suppliers of inputs, since these agents have faced default in loans and accounts payable. Agricultural traders lose out when faced with a shortage of raw materials, and rural shopkeepers and small businesses suffer when local incomes and therefore demand for their services fall. Some more dramatic evidence is seen from studies of severe drought, showing that, in percentage terms, income losses exceed the fall in production due to productive collapse, reducing employment and wages, non-farm income and asset prices (Webb and von Braun, 1994; Hazell and Ramasamy, 1991).

Agricultural insurance promotes more stable and safer production in agriculture; in addition to reducing farmers' uncertainty and the need to create individual savings accounts or funds, since the need for cash reserves is reduced (Raulston et al., 2010; Fishlow and Vieira Filho, 2020).

In agriculture, among the market failures that inhibit the formation of safer systems, the occurrence of asymmetric information between contractor and insurer stands out; adverse selection, given by the definition and arbitration of an average price for all; and moral hazard, that is, changing the behavior of an economic agent when not properly monitored by the other party, increasing the likelihood of damage or accident (Loyola et al, 2013; Stiglitz and Walsh, 2003)

Ferreira and Ferreira (2009) sought to evaluate the main international experiences of rural insurance, mainly in the United States and Canada. These authors stressed the important role of the government in making insurance possible in the event of claims, in order to generate greater sustainability of the production process, thus providing greater income stability, on the economic side, and generating jobs for farmers and their families, on the social side (Note 4).

Following this line of reasoning, Fornazier et al. (2012) analyzed the importance of rural insurance in reducing risks in agriculture, making a comparison with other international experiences. The conclusion was that the structuring of insurance needs greater efficiency, with greater cooperation between the market, government, producers, cooperatives, universities and research centers. The institutional framework can accelerate the process of developing the rural insurance market, both in the public and private sectors.

Early research on risk management practices suggests that these initiatives are surprisingly effective, even in many drought-prone areas (Walker and Jodha, 1986; Bhattamishra and Barrett, 2010). However, such works are not exempt from costs and limitations. In drought-prone areas, such as in India and Burkina Faso, the data suggests that farmers have to sacrifice 12 to $15 \%$ of average income to reduce risk (Sakurai and Reardon, 1997).

Siddiqui and Das (2017) point out that in India, 70\% of the country's population lived in rural areas, being involved in agriculture and agricultural activities. If there was a crop failure, farmers' lives would be directly or indirectly affected, leading to a widespread financial crisis. The main reason for the failure of the harvest was adverse weather conditions or pests. It was shown that $39 \%$ of the variation in the expected crop failure rates was explained by soil and climate. 
Thus, insurance provided the scope to reduce losses and increase economic security, although it was true that access to insurance coverage would depend on levels of literacy and / or awareness, as well as guaranteed income.

In Brazil, rural insurance programs have played an important role in the risk management of agricultural products in several countries (Ozaki, 2010), mainly with government support, through subsidies, thus leading to a greater participation of producers in the respective programs (Ozaki, 2007).

According to Medeiros (2013), the government extends the debts of rural credit producers in the absence of an agricultural insurance policy and in the presence of claims, which may reduce revenues and, consequently, productive investments. In general, a policy to promote the sector that does not incorporate the issue of insurance becomes ineffective in terms of its objectives, as well as burdening the public budget of the State. It should be noted that the renegotiation of debts, which have been generated by adverse events, only extends the resolution of the problem in maintaining the stability of the productive system. In this sense, the performance of effective policies can reduce pressure on the public budget, signaling that partial payment of the cost of taking out insurance would be an optimal decision in the set of alternatives.

There have been several attempts over time by the Brazilian federal government to implement a system of productive security in agriculture, which comes since the 1930s with the creation of insurance against hail. In the 1950s, the National Agricultural Insurance Company (Companhia Nacional do Seguro Agrícola - CNSA) and the Agricultural Insurance Stability Fund (Fundo de Estabilidade do Seguro Agrícola - FESA) were created. In the same year that the Brazilian Agricultural Research Corporation (Empresa Brasileira de Pesquisa Agropecuária - Embrapa) was created, in 1973, the Agricultural Activity Guarantee Program (Programa de Garantia da Atividade Agropecuária PROAGRO) was created. More recently, the Rural Insurance Premium Subsidy Program (Programa de Subvenção ao Prêmio do Seguro Rural - PSR) was established in 2003, with the objective of promoting access to rural insurance, aiming at greater income stability for the producer, encouraging the use and adoption of new technologies in production, as well as modernizing agricultural management (Ferreira and Ferreira, 2009).

Ozaki (2010) sought to analyze the growth of the PSR Subsidy Program in Brazil. The author concluded that, despite the expansion of the program, it concentrated on the State of Paraná, thus suggesting that the state has a lower risk than other soybean producing states. However, when comparing with the State of Mato Grosso, the municipalities of Paraná have a higher risk than the main cities of Mato Grosso.

Adami and Ozaki (2012) sought to analyze the behavior of PSR direct premiums for 2011. The results showed that the amounts allocated were insufficient to maintain the insurance growth trend, and the market may suffer a setback in order to avoid the market stagnation and the helplessness of a large number of producers exposed to the problems arising from weather conditions.

Macedo et al. (2013) analyzed the evolution of the PSR over the period from 2006 to 2010, comparing the main results with some international experiences. The authors concluded that, although the program proves to be beneficial, the insurance policy has little scope for action in relation to the total national agricultural production.

Silva et al. (2014) also sought to evaluate the PSR program, in the period from 2005 to 2012, in terms of universal access to rural insurance. The results showed that the program contributed to the expansion of security in agricultural production. However, the contracts were concentrated in the southern region, mainly in Paraná, with a large presence of soybeans as the main assured product.

According to Medeiros (2013), the partial effectiveness of the program was shown, mainly with the interest in continued adherence. From an economic point of view, the need to burden the National Treasury with debt renegotiations was reduced, which demonstrated the importance of such a political instrument. However, there was a need to move on to another point, such as securing budgetary resources in a timely manner.

Loyola et al. (2016) evaluated the recent evolution of the PSR insurance subsidy program and its main variables: area of the insured amount, policies, average area, producers, total premiums involved and total subsidy. The results showed that the PSR program was responsible for expanding the rural insurance market, encouraging and providing farmers with access to agricultural insurance, subsidizing the premium rate. Although this expansion was slow and gradual, in 2013 Brazil had about $13.8 \%$ of the agricultural area covered by rural insurance. This, according to the authors, reveals the need to expand the program to popularize this important instrument for mitigating the problems arising from the risk inherent in production.

Gouveia (2016) analyzed the causes of low adherence to rural insurance in Brazil. Results suggest that the Brazilian insurance market at the time was still incipient, as less than $10 \%$ of the national harvest had been insured; and, when 
compared to the results with countries such as the United States, the adhesion rate was very low, partly due to the nature of the business risk, but also due to the absence of public policies for subsidizing the insurance market.

Tabosa and Oliveira (2019), using the propensity score matching method, analyzed the impact of the PSR program on the productivity obtained from rural insured producers in the different Brazilian regions. The results show that insured producers obtained higher productivity than non-insured ones in all Brazilian regions, with the most expressive result featured in the South region of the country.

In general, the statistics seem to suggest that insurance policies are concentrated in regional terms, basically in the states of the South and Southeast regions of the country. However, there is an expansion in the number of contracts in the Center-west region. In terms of products, there is a concentration in grain production, with soybeans and wheat as the main insured crops.

\section{Methodology}

This section features the data used for the intended research, as well as the econometric methodology.

\subsection{Data}

The data used were extracted from the Atlas of Rural Insurance, from the Ministry of Agriculture, Livestock and Supply (Ministério da Agricultura, Pecuária e Abastecimento - MAPA), composed of annual information from the municipalities of the MATOPIBA region, corresponding to the period from 2008 to 2019 (see Table 1).

Table 1. Description of the variables

\begin{tabular}{l}
\hline Variables \\
\hline Producers: number of insured producers \\
\hline Insurance Policies: Number of Insurance Policies \\
\hline Area: Area Planted by the insured producer (in hectares) \\
\hline Productivity: quantity produced in kilograms per hectare \\
\hline Amount: Insured amount by the government for the producer (in R\$)*
\end{tabular}

Source: MAPA. Prepared by the authors. *Value adjusted by the Brazilian General Price Index (Índice Geral de Preços - Disponibilidade Interna - IGP-DI), base year 2019.

For this work, municipalities in the MATOPIBA region that had information for all variables in Table 1 were used; and throughout the analyzed period (Note 5). That is, all those municipalities that had at least one producer and a contracted PSR policy over the entire period from 2008 to 2019.

\subsection{Model}

To analyze the impact of the for the PSR program on the productivity of policyholders in the MATOPIBA region of Brazil, the panel VAR model was opted. As mentioned by Canova and Cicarelli (2013), Panel VARs are built with the same logic of standard VARs but, by adding a cross sectional dimension, they are a much more powerful tool to address the impact of policies.

As also commented in Canova and Cicarelli (2013), the variables are assumed to be endogenous and interdependent, as is the case in the regular VAR, but a cross sectional dimension is added. Thus, regular VAR model would have as its structure (Note 6):

$$
Y=A_{0}(t)+A(L) Y_{t-1}+u_{i t}, \text { where } u_{t} \sim \operatorname{iid}\left(0, \Sigma_{u}\right)
$$

In order to measure the effects of rural insurance shocks on the agricultural productivity of policyholders in the MATOPIBA region, the following model, a panel VAR, was estimated:

$$
y_{i, t}=A_{0 i}(t)+A_{i}(L) Y_{t-1}+u_{i t}
$$

The index $i$ is generic, representing the municipalities $y_{i, t}$ is the vector of endogenous variables in the model. $Y_{t}$ is a stacked version of $y_{i, t}$. $A_{0 i}(t)$ has all the deterministic components of the data. $A_{i}(L)$ is the polynomial lag operator. Lastly, $u_{i t}$ is a $G x l$ of random errors? Furthermore, $A_{0 i}$ and $A_{i}$ are dependent of each unit $i$ (Canova and Cicarelli, 2013). 
When estimating panel models, it is necessary to obtain the unobserved heterogeneity of the states. Thus, this work uses the fixed least squares effects estimator for panel data. The identification of the model was performed through recursive ordering, following the work developed by Blanchard and Perotti (2002) and Bénétrix and Lane (2012). The productivity responses to shocks from the Rural Insurance Premium Subsidy Program were obtained from the impulse-response functions (Note 7).

Before estimating the models for the VAR Panel, however, it is important to verify the existence of a unit root in the observed series. For this, we opted to use the test developed by Harris and Tzavalis (1999), as we work with a small T sample (between the years 2008 and 2018, totaling 11 years). Harris and Tzavalis (1999) built a unit root test that assumes the correction of the time dimension $\mathrm{T}$. If not, the asymptotic properties are established assuming that $\mathrm{T}$ tends to infinity, which may lead to an incorrect inference. The test presents as a null hypothesis the presence of a unit root, against the alternative hypothesis of the absence of a unit root.

\section{Results}

\subsection{Descriptive Analysis of the PSR Program in the MATOPIBA Region}

In this section, some results of the descriptive analysis of the variables are presented: number of producers, number of insurance policies, productivity and planted area for the sample of municipalities that make up the MATOPIBA region.

Table 2 shows the spatial distribution (in percentage) of the variables in each municipality in the sample. It is observed that, within the municipalities that compose the sample, there is a concentration of the number of insurance policies and insured producers in the state of Bahia $(75.76 \%$ and $75.91 \%$, respectively), mainly in the municipalities Formosa do Rio Preto (Note 8) (30.37\% and 30.31\%, respectively) and São Desidério (Note 9) (14.58\% and $14.29 \%$, respectively). On the other hand, the state of Tocantins has the lowest number of insurance policies and producers (6.12\% and 6.48\%, respectively). The main economic activity of the municipalities of Formosa do Rio Preto and São Desidério is the production of soybeans, which is the main product guaranteed by the PSR program (Note 10).

This concentration in the state of Bahia also occurs with the variables planted area (75.93\%) and insured amount (77.17\%). The productivity variable obtained is also shows a certain concentration in Bahia, but in a more discreet way (40.15\%), while the other states have a productivity of 17.19\% (Tocantins), $16.57 \%$ (Piauí) and 26.06\% (Maranhão).

Table 2. Spatial distribution (in \%) of the variables of each municipality in the sample - MATOPIBA region

\begin{tabular}{|c|c|c|c|c|c|}
\hline Municipalities & $\begin{array}{l}\text { N. of insurance } \\
\text { policies }\end{array}$ & $\begin{array}{ll}\text { N. } & \text { of } \\
\text { Producers }\end{array}$ & Productivity & Planted Area & $\begin{array}{l}\text { Insured } \\
\text { amount }\end{array}$ \\
\hline Palmeirante/TO & 0.86 & 1.46 & 4.30 & 0.85 & 0.82 \\
\hline Guaraí/TO & 1.39 & 1.45 & 3.91 & 0.89 & 0.80 \\
\hline Rio dos Bois/TO & 1.57 & 1.69 & 4.61 & 1.32 & 1.17 \\
\hline Porto Nacional/TO & 2.30 & 1.88 & 4.37 & 2.26 & 2.73 \\
\hline Total TO & 6.12 & 6.48 & 17.19 & 5.32 & 5.52 \\
\hline Baixa Grande do & & & & & \\
\hline Ribeiro/PI & 1.43 & 1.38 & 5.75 & 1.87 & 1.91 \\
\hline Santa Filomena/PI & 1.72 & 1.81 & 4.56 & 1.71 & 1.53 \\
\hline Uruçuí/PI & 5.88 & 5.77 & 6.26 & 5.17 & 4.73 \\
\hline Total PI & 9.03 & 8.96 & 16.57 & 8.75 & 8.17 \\
\hline Barreiras/BA & 7.13 & 7.46 & 5.58 & 6.48 & 6.64 \\
\hline $\begin{array}{lll}\text { Formosa } & \text { do } & \text { Rio } \\
\text { Preto/BA } & & \\
\end{array}$ & 30,37 & 31.00 & 5.67 & 30,32 & 28.38 \\
\hline Eduardo & & & & & \\
\hline Magalhães/BA & 8.73 & 8.75 & 5.54 & 7.49 & 7.49 \\
\hline Riachão das Neves/BA & 5.29 & 5.13 & 4.79 & 6.03 & 6.54 \\
\hline São Desidério/BA & 14.58 & 14.29 & 6.20 & 14.20 & 17.68 \\
\hline Correntina/BA & 5.15 & 4.56 & 6,80 & 5.66 & 5.27 \\
\hline
\end{tabular}




\begin{tabular}{llllll}
\hline Jaborandi/BA & 4.94 & 4.72 & 5.57 & 5.75 & 5.17 \\
\hline Total BA & $\mathbf{7 5 . 7 6}$ & $\mathbf{7 5 . 9 1}$ & $\mathbf{4 0 . 1 5}$ & $\mathbf{7 5 . 9 3}$ & $\mathbf{7 7 . 1 7}$ \\
\hline Grajaú/MA & 0.74 & 0.83 & 5.04 & 0.60 & 0.42 \\
\hline Alto Parnaíba/MA & 0.91 & 0.90 & 5.43 & 0.81 & 0.67 \\
\hline Balsas/MA & 3.67 & 3.72 & 5.01 & 4.07 & 3.93 \\
\hline Tasso Fragoso/MA & 2.04 & 1.91 & 6.17 & 2.86 & 2.71 \\
\hline Loreto/MA & 1.29 & 1.31 & 4.41 & 1.64 & 1.40 \\
\hline Total MA & $\mathbf{8 . 6 5}$ & $\mathbf{8 . 6 7}$ & $\mathbf{2 6 . 0 6}$ & $\mathbf{9 . 9 8}$ & $\mathbf{9 . 1 3}$ \\
\hline Total & $\mathbf{1 0 0}$ & $\mathbf{1 0 0}$ & $\mathbf{1 0 0}$ & $\mathbf{1 0 0}$ & $\mathbf{1 0 0}$ \\
\hline
\end{tabular}

Source: Research data. Prepared by the authors.

Figure 1 shows the number of insurance policies in the PSR program contracted in the municipalities that make up the sample of the MATOPIBA region between the years 2008 to 2019. It can be noted that, in 2009, the number of contracted insurance policies reached 1,181 units. In 2010, this value decreased to 949, due to the international crisis, but grows again in $2013(1,150)$. In 2014, the PSR program reached the highest number of insurance policies contracted (1,187 policies). However, in 2015, this number decreased considerably to 138 insurance policies, mainly due to the period of economic and political crisis in the Brazil, which caused budget constraints in the federal public sector over the period 2015 to 2018. Since 2016, a small recovery, to 402 contracted in 2019.

It is worth mentioning that the performance of the PSR program depends directly on the volume of resources available, which in 2010 was only approximately $\mathrm{R} \$ 200$ million, which was reflected in the drop in the number of subsidized policies. As for the 2014/2015 biennium, the drastic drop in the number of insurance policies occurred due to an amendment to Law No. 10823/2003, which allowed part of the 2015 budget to be used to subsidize policies contracted in 2014, in an exceptional way (TABOSA and VIEIRA FILHO, 2018). Lastly, it is worth mentioning that the PSR program has been facing successive budget constraints in recent years, which is invariably reflected in the numbers achieved. In addition, other factors should also be taken into account, such as changes in percentage and subsidy limits, as well as in the levels of productivity coverage that have occurred over the years, among other factors.

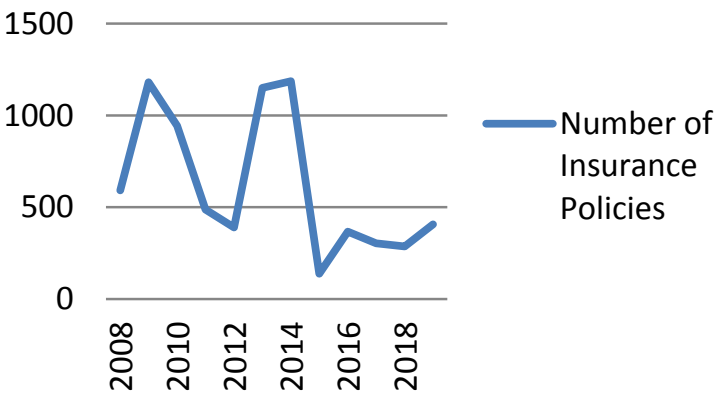

Figure 1. Number of PSR Policies the municipalities of the MATOPIBA region - 2008 to 2019

Source: Prepared by the authors using data from MAPA (2020).

Figure 2 shows the number of producers who joined the PSR program in the sample municipalities in the MATOPIBA region. It can be observed that in 2009 , the number of producers was equal to 965 . In 2010, this number decreased to 815 producers, due to the international crisis. In 2014, the PSR program reached its largest number of producers who joined its program (927 producers). Consequently, in 2015, this number reduced considerably to 133 producers, due to the Brazilian economic and political crisis, which besides promoting a fall in the Brazilian domestic product, generated a crisis of mistrust in the conduct of Brazilian economic policy (Note 11). In addition, this reduction was also due to the budget constraint that impacted the ability of the federal government to pay the subsidy on the insurance premium, mentioned earlier in this section. 


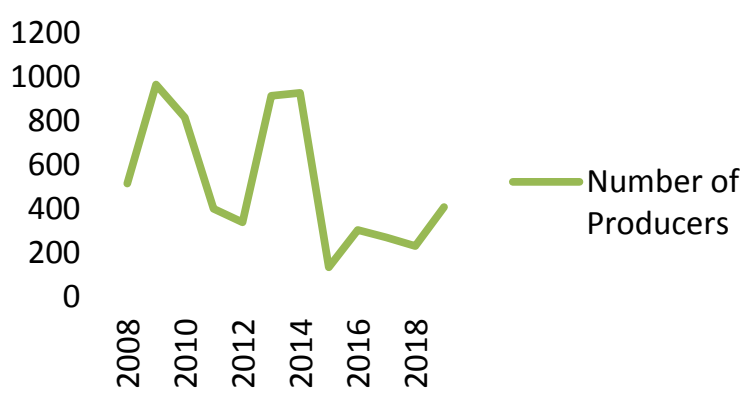

Figure 2. Number of PSR Insured Producers the municipalities of the MATOPIBA region - 2008 to 2019

Source: Prepared by the authors using data from MAPA (2020).

Figures 3, 4 and 5 show the obtained productivity, planted area and insured amount of the producers who adhered to the PSR program in the MATOPIBA region, respectively. Regarding the productivity obtained (graph 3), there is an increasing trajectory over the analyzed period. The years 2012 (42.6 tonnes), 2016 (42.3 tonnes) and 2019 (45.1 tonnes) presented the s results, mainly in 2019, which provides a positive outlook for the year 2020. This result due to the expansion of soy production in the municipalities of Formosa do Rio Preto, Barreiras and São Desidério (Note 12).

In relation to the planted area and the insured amount, both follow the same trajectory as the series of number of insurance policies and producers. The trajectories peaked in 2009, then reduced until 2012, due to the international crisis. As of 2012, there is an increase in the amount insured until 2013 ( $\mathrm{R} \$ 610,606,278.70)$ and for the planted area in 2014 (363,584 hectares). In 2015, there was a considerable reduction both in the planted area and the insured amount, due to the Brazilian economic crisis, which caused a cut in the budget for the PSR program, as mentioned above.

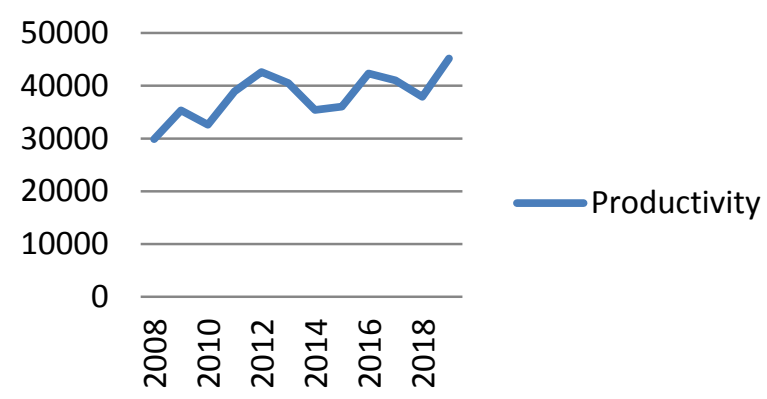

Figure 3. Productivity obtained by the insured producers in the PSR program in the municipalities of the MATOPIBA region - 2008 to 2019

Source: Prepared by the authors using data from MAPA (2020).

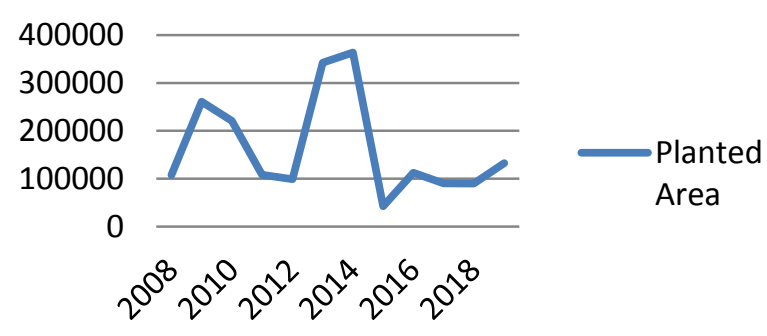

Figure 4. Planted area by the PSR insured producers in the municipalities of the MATOPIBA region - 2008 to 2019 Source: Prepared by the authors using data from MAPA (2020). 


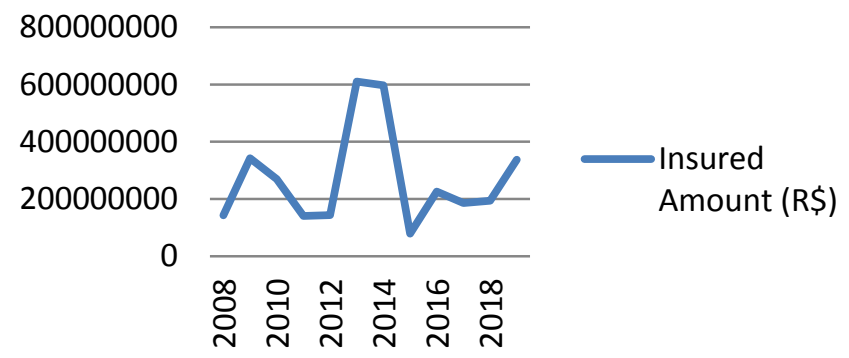

Figure 5. Insured amount through the PSR program in the municipalities of the MATOPIBA region - 2008 to 2019 Source: Prepared by the authors using data from MAPA (2020).

\subsection{Model Results for the MATOPIBA Region}

In this subsection, the results for the analyzed municipalities of the MATOPIBA region are presented. Table 3 shows the descriptive statistics of the variables used. Initially, it can be observed that, for all variables, the standard deviation is considered high, denoting the great variability of the values. This is due to the set of several municipalities analyzed in the sample. On average per municipality, 27.78 producers joined the PSR program, which purchased an average of 32.47 insurance policies, from 2008 to 2019. The average planted area (in hectares) was 8,793.33. The average amount insured was $\mathrm{R} \$ 14,334,218.5$. The average productivity (kilograms per hectare) was 71,274.69, that is, around 71 tons per hectare.

Table 3. Descriptive statistics of the variables - 2008 to 2019

\begin{tabular}{lllll}
\hline Variables & Mean & Std. Dev. & Minimum & Maximum \\
\hline Producers & 27.78 & 46.64 & 1 & 301 \\
\hline Insurance Policies & 32.47 & 57.51 & 1 & 351 \\
\hline Planted Area (in hectares) & $8,793.33$ & 14911.94 & 53 & 98,951 \\
\hline Produtctivity (kg/hectares) & $71,274.69$ & 10016.93 & 22.39 & $1.45 \mathrm{e}+07$ \\
\hline Insured Amount (R\$) & $14,334,218.5$ & $24,549,561.5$ & $64,498.66$ & $188,329,967.00$ \\
\hline
\end{tabular}

Source: Prepared by the authors.

Table 4 shows the result of the Harris-Tzavalis unit root test (1999). When analyzing the results, it was found that all series were stationary in level. In this way, the PVAR models are estimated with all variables in level.

Table 4. Harris-Tzavalis Unit Root Test Results (1999)

\begin{tabular}{lllll}
\hline Series & I (d) & Statistic & Z & p-value \\
\hline Producers & I $(0)$ & -0.0289 & -5.8940 & 0.0000 \\
\hline Insurance Policies & I $(0)$ & -0.0031 & -5.5576 & 0.0000 \\
\hline Planted Area & I $(0)$ & 0.0558 & -4.7902 & 0.0000 \\
\hline Insured Amount & I (0) & 0.2549 & -6.4118 & 0.0000 \\
\hline Producitivity & I $(0)$ & -0.3870 & $-10,5655$ & 0.0000
\end{tabular}

Source: Prepared by the authors. I (d) is the number of differences in the model. 
The structural coefficients, or contemporary effects, in the system, are shown in Table 5. The contemporary effect of the numbers of producers, number of insurance policies and the insured amount is positive, indicating that, at the moment, the first shock is positive. The effects of the planted area were negative. This occurs because of the effect between productivity and the planted area, as when there is an increase in planted area, the first response in productivity is negative.

Table 5. Contemporary model effects

\begin{tabular}{ll}
\hline & Productivity \\
\hline Producers & 0.7700 \\
\hline Insurance Policies & 10.0559 \\
\hline Planted Area & -0.0470 \\
\hline Insurance Amount & 66,05 \\
\hline
\end{tabular}

Source: Prepared by the authors.

After analyzing the contemporary effects, the impulse-response functions for the obtained productivity were estimated, with shocks in the number of producers (Producers), in the number of policies (Policies), planted area and in the assured importance (Importance). Figure 6 shows the shock impulse-response function in the number of producers with response in productivity. It is observed that, in Figure 1, the immediate effect of a shock on the number of producers on productivity is positive, which persists until the second year, when it begins to have a negative response in the third year. Then there is a positive jump in the fourth year, and then a reduction until the sixth year, then it softens over time.

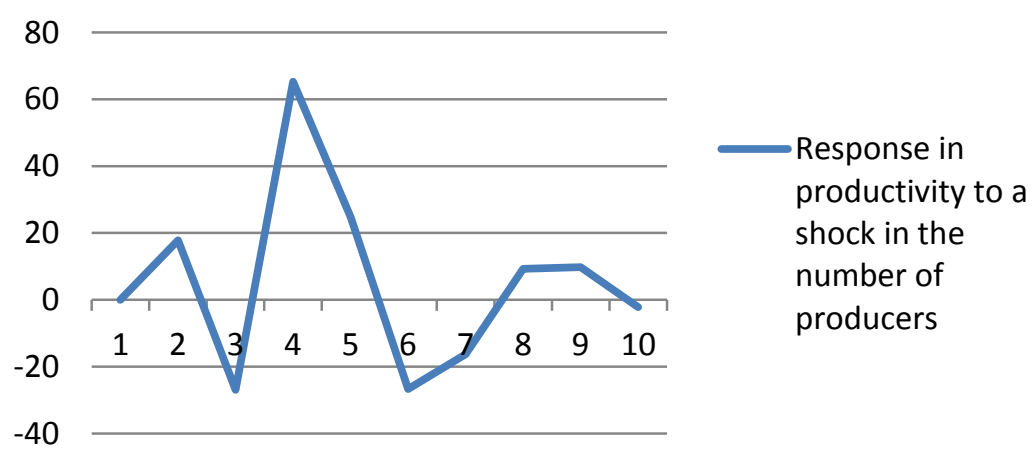

Figure 6. Response of productivity to shocks in the number of producers

Source: Prepared by the authors.

Note: The dashed lines represent the 95\% confidence interval.

Figure 7 represents the impulse-response function of a shock in the number of insurance policies with a response in productivity. The shock in the number of insurance policies causes an increase in productivity, lasting until the second year, where from that moment it begins to show a negative response until the fourth year, in which it oscillates between an increase and decrease, stabilizing in time from the sixth year onwards. The initial positive impact indicates that, the moment producers acquire an insurance policy, they to increase their productivity, given that their risk of loss of production decreases. This result corroborates those found in Tabosa and Vieira Filho (2018). 

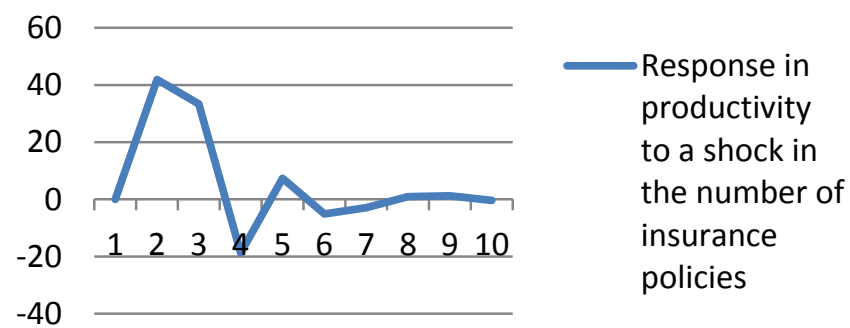

Figure 7. Response of productivity to shocks in the number of insurance policies

Source: Prepared by the authors.

Note: The dashed lines represent the 95\% confidence interval.

The initial negative response of productivity in relation to a shock in the planted area is evident in Figure 8 . This negative response extends to the fourth year, then returns to growth until the sixth year, softening in the period thereafter. Insurance aims to avoid the risk of crop loss by producers, and not to expand the planted area (Tabosa and Vieira Filho, 2018; Adama and Osaki, 2012; Medeiros, 2013; Silva et al., 2014). Thus, this negative response from productivity to shocks in the planted area is due to the fact that the planted area does not boost the productivity of insured producers, since producers, when purchasing insurance, seek to protect themselves from losses, not increase investments.

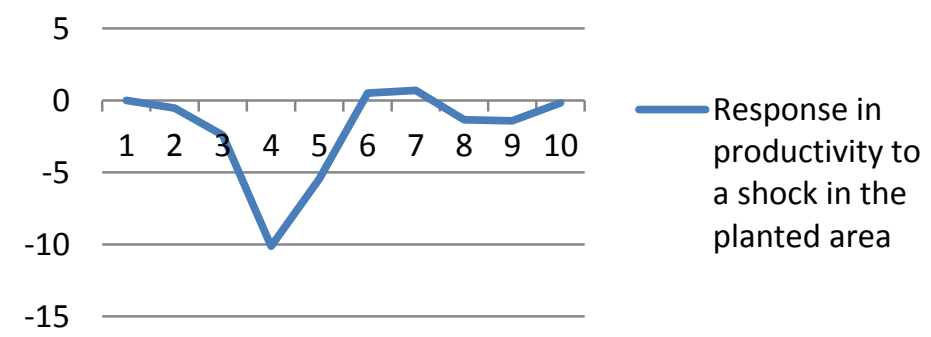

Figure 8. Response of productivity to shocks in the planted area

Source: Prepared by the authors.

Note: The dashed lines represent the 95\% confidence interval.

Lastly, Figure 4 shows the productivity response to a shock in the insure amount. The initial response is positive until the second year. Then, there is a sharp drop until the fifth year, growing again and softening over time. The results corroborate those of Tabosa and Vieira Filho (2018).

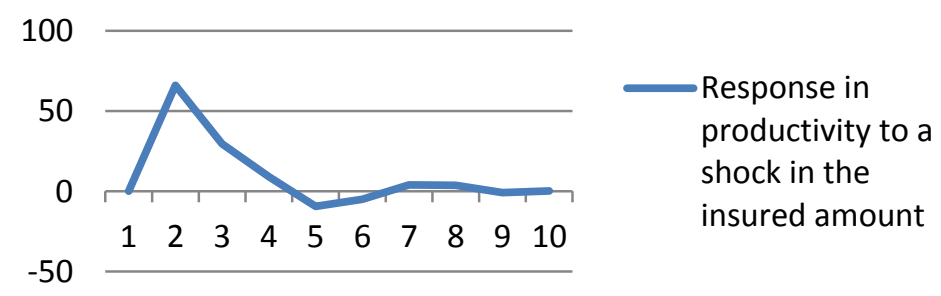

Figure 9. Response of productivity to shocks in the assured importance

Source: Prepared by the authors.

Note: The dashed lines represent the $95 \%$ confidence interval. 


\section{Concluding Remarks}

The present work sought to evaluate the impact of the Rural Insurance Premium Subsidy Program (Programa de Subvenção ao Prêmio do Seguro Rural - PSR) in Brazil, on the productivity of insured producers in the MATOPIBA region of the country, between the years 2008 to 2019. For that purpose, municipalities were selected that had at least one insured producer throughout the analyzed period. The variables used were the number of producers, the number of insurance policies, the planted area, the productivity obtained and the insured amount of the producers. The methodological procedure was based on Auto-regressive Vectors (VAR) for panel data.

The results showed a concentration, of all the variables used, in the state of Bahia, mainly in the planted area (75.93\%) and insured amount (77.17\%). The productivity variable obtained also shows a concentration in Bahia. This concentration of PSR in Bahia is mainly due to the municipalities of Formosa do Rio Preto and São Desidério, which have soy production as their main economic activity. This activity is predominant among insured producers in the region.

The variables number of producers and contracted insurance policies reached their highest level in 2014, after which they fell sharply the following year, due to the economic crisis and the cuts in budget resources allocated to the program. The productivity variable showed an increasing trajectory over the analyzed period, while the variables planted area and insured amount showed similar behavior, with peaks during the international crisis of 2008/2009 and in 2014.

When performing the estimates of the Auto-regressive Vectors (VAR) model for panel data, it was found that the responses presented in the impulse response functions on the productivity obtained after a shock in the other variables, except the planted area variable, the other variables showed initial (short-term) responses with positive results until the second year. The average time for responses to smooth over time occurs from the sixth year onwards. These results corroborate with those found by Tabosa and Vieira Filho (2018) and Adami and Osaki (2012).

As a suggestion, it would of great relevance that the rural producer in the MATOPIBA region has greater access to the analyzed program, as an instrument to guarantee their production, thus reducing the degree of risk of losses, and mainly the small producer, as a form of guaranteeing new investments, thus reducing their degree of vulnerability.

\section{References}

Adami, A. C. De. O., \& Ozaki, V. A. (2012). Modelagem estatística dos prêmios do seguro rural. Revista de Política Agrícola, 21(1), 60-75. Retrieved from https://seer.sede.embrapa.br/index.php/RPA/article/view/73

Barbosa Filho, F. De. H. (2017). A crise econômica de 2014/2017. Estudos Avançados, 31(89). Retrieved from https://www.scielo.br/pdf/ea/v31n89/0103-4014-ea-31-89-0051.pdf

Benetrix, A. S., \& Lane, P. R. (2012). The cyclical conduct of Irish Fiscal Policy. The World Economy, 35(10), 1277-1290. Retrieved from https://papers.ssrn.com/sol3/papers.cfm?abstract_id=2161174

Bhattamishra, R., \& Barret, C. B. (2010). Community-based risk management arrangements: a review. World Development, 38(7), 923-932.

Blanchard, O., \& Perotti, R. (2002, November). An empirical characterization of the dynamic effects of changes in government spending and taxes on output. The Quarterly Journal of Economics, 117(4), 1329-1368. Retrieved from https://www.jstor.org/stable/4132480

Brasil-Ministério Da Agricultura, Pecuária E Abastecimento. (2017). PSR - Programa de Subvenção do Prêmio do Seguro Rural. Retrieved from http://indicadores.agricultura.gov.br/atlasdoseguro/index.htm 2017a

Brasil-Ministério Da Agricultura, Pecuária E Abastecimento. (2017). Limites percentuais de subvenção do Seguro Rural.

http://www.agricultura.gov.br/politica-agricola/se-guro-rural/limites-percentuais-de-subvencao2017b

Buainain, A. M., \& Garcia, J. R. (2015). Evolução recente do agronegócio no Cerrado Nordestino. Estudos Sociedade $e$ Agricultura (UFRRJ), 23, 166-195. Retrieved from https://revistaesa.com/ojs/index.php/esa/article/view/439

Buainain, A. M., Alves, E., Silveira, J. M., \& Navarro, Z. O. (2014). Mundo rural no Brasil do século 21: a formação de um novo padrão agrário e agrícola (p. 64). Brasília: Embrapa. Retrieved from https://www.embrapa.br/busca-de-publicacoes/-/publicacao/994073/o-mundo-rural-no-brasil-do-seculo-21-a-for macao-de-um-novo-padrao-agrario-e-agricola 
Buainain, A. M., Garcia, J. R., \& Vieira Filho, J. E. R. (2017). Dinâmica da Economia e Agropecuária no MATOPIBA. Texto para discussão 2283 - Instituto de Pesquisa Econômica Aplicada. Brasília: Rio de Janeiro: Ipea. Retrieved from https://www.ipea.gov.br/portal/images/stories/PDFs/TDs/td_2283zzzzkkkk.pdf

Campos, S. K., \& Navarro, Z. (2013). A pequena produção rural e as tendências do desenvolvimento agrário brasileiro: ganhar tempo é possivel?. Brasília: CGEE. Retrieved from https://www.cgee.org.br/documents/10195/734063/Livro_Pequena_produ_rural_9525.pdf/c6deb8b4-9523-47a0 -ac11-c0eed33b2f99?version=1.2

Canova, F., \& Cicarelli, M. (2013). Panel Vector Autoregressive Models A Survey. Working Paper Series No 1507. European Central Bank. Frankfurt. Retrieved from https://www.ssrn.com/abstract=2201610

Ferreira, A. L. C. J., \& Ferreira, L. Da. R. (2009). Experiências internacionais de seguro rural: as novas perspectivas da política agrícola para o Brasil. Econômica. Rio de Janeiro, 11(1), 131-156. Retrieved from https://periodicos.uff.br/revistaeconomica/article/download/34875/20131

Fishlow, A., \& Vieira Filho, J. E. R. (2020). Agriculture and industry in Brazil: innovation and competitiveness (p. 224). New York: Columbia University Press.

Fornazier, A., Souza, P. M. De., \& Ponciano, N. J. (2012). A importância do seguro rural na redução de riscos na agropecuária. Revista de Estudos Sociais, 14(28). Retrieved from https://dialnet.unirioja.es/descarga/articulo/4690028.pdf

Gasques, J. G. (2016). Produtividade da agricultura brasileira: a hipótese da desaceleração. In J. E. R. Vieira Filho, \& J. G. Gasques (Eds.), Agricultura, transformação produtiva e sustentabilidade (pp. 143-164). Brasília: Ipea. Retrieved from http://repositorio.ipea.gov.br/bitstream/11058/9241/1/Produtividade\%20da\%20agricultura.pdf

Gasques, J. G., Bacchi, M. R. P., Rodrigues, L., Bastos, E. T., \& Valdes, C. (1992). Produtividade da agricultura brasileira: a hipótese da desaceleração. In P. Vieira Hall (Ed.), The bootstrap and Edgeworth expansion. Springer, New York.

Gasques, J. G., Bastos, E. T., Valdes, C., \& Bacchi, M. R. P. (2012). Total fator productivity in Brazilian agriculture. In K. O. Fuglie, S. L. Wang, \& V. E. Ball (Eds.), Productivity growth in agriculture: an international perspective (pp. 145-162). Oxfordshire: CAB International.

Gasques, J. G., Vieira Filho, J. E. R., \& Navarro, Z. (2010). A agricultura brasileira: desempenho, desafios e perspectivas. $\quad$ Brasília: $\quad$ Ipea. $\quad$ Retrieved from https://www.ipea.gov.br/portal/index.php?option=com_content\&view=article\&id=6480

Harris, R. D. F., \& Tzavalis, E. (1999). Inference for unit roots in dynamic panels where the time dimension is fixed. Journal of Econometrics, 91, 201-226. $\quad$ Retrieved from https://www.sciencedirect.com/science/article/pii/S0304407698000761

Hazell, P. B. R., \& Ramasamy, C. (1991). The green revolution reconsidered: The impact of the high yielding rice varieties in South India. Baltimore: Johns Hopkins University Press.

Heckman, J. J., Lalonde, R. J., \& Smith, J. A. (1999). The economics and econometrics of active labor market programs. In O. Ashenfelter, \& D. Card (Eds.), Handbook of labor economics (1st ed., Vol. 3, pp. 1865-2097). Elsevier.

Hess, U., \& Hazell, P. (2016). Innovations and Emerging Trends in Agricultural Insurance: How can we transfer natural risks out of rural livelihooods to empower and protect people? (p. 56). Deutsche Gesellschaft für Internationale Zusammenarbeit (GIZ). Eschborn.

Instituto Brasileiro De Geografia E Estatística-IBGE. (2017). Censo Agropecuário (Several years). Rio de Janeiro. Retrieved from https://www.ibge.gov.br/estatisticas/economicas/agricultura-e-pecuaria/21814-2017-censo-agropecuario.html

Instituto Brasileiro De Geografia E Estatística-IBGE. (2020). Informações municipais. Rio de Janeiro.

Iturrioz, R. (2009). Agricultural Insurance. Primer Series on Insurance, the World Bank, Washington, DC.

Loyola, P., Moreira, V. R., \& Veiga, C. P. (2016). Analysis of the Brazilian program of subsidies for rural insurance premium: evolution from 2005 to 2014. Modern Applied Science, 10(7), 87-98. 
Macedo, L. O. B., Pacheco, A. B., \& Santo, E. S. Do. E. (2013). A evolução do Programa de Subvenção do Prêmio do Seguro Rural: uma avaliação do período de 2006-10. Indicadores Econômicos FEE, Porto Alegre, 40(4), 99-112. Retrieved from https://revistas.fee.tche.br/index.php/indicadores/article/view/2810

Medeiros, E. A. De. (2013). Avaliação da Implementação do Programa de Subvenção do Prêmio do Seguro Rural. Revista de Economia e Sociologia Rural, 51(2), 295-308. Retrieved from https://www.scielo.br/scielo.php?script=sci_arttext\&pid=S0103-20032013000200005\&lng=pt\&nrm=iso\&tlng= $\mathrm{pt}$

Ozaki, V. (2007). O papel do seguro na gestão de risco agrícola e os empecilhos para o seu desenvolvimento. Revista Brasileira de Risco e Seguro (Online), 2, 75-92. Retrieved from http://www.rbrs.com.br/arquivos/RBRS4-5\%20Vitor\%20Ozaki\%20On\%20Line.pdf

Ozaki, V. (2008). Em busca de um novo paradigma para o seguro rural no Brasil. Revista de Economia e Sociologia Rural, $\quad 46(1), \quad 97-119 . \quad$ Retrieved $\quad$ from https://www.scielo.br/scielo.php?script=sci_arttext\&pid=S0103-20032008000100005

Ozaki, V. (2010). Uma digressão sobre o Programa de Subvenção ao Prêmio do Seguro Rural e as implicações para o futuro deste mercado. Revista de Economia e Sociologia Rural, 48(4), 495-514. Retrieved from https://www.scielo.br/scielo.php?script=sci_arttext\&pid=S0103-20032010000400001\&lng=en\&nrm=iso\&tlng= $\mathrm{pt}$

Petrovic, Z., Njegomir, V., \& Počuča, S. (2013). Characteristics of agricultural insurance: the case of countries of former Yugoslavia region. Economics of Agriculture, 60(4), 729-743.

Raulston, J. M., Richardson, J. W., Outlaw, J. L., \& Knapek, G. M. (2010). Does Crop Insurance Reduce the Need for Cash Reserves in Savings Accounts?. Paper presented at the SAEA Annual Meeting, Orlando.

Rosenzweig, M. R., \& Binswanger, H. P. (1992). Wealth, weather risk and the profitability of agricultural investment. Economic Journal, 103, 56-78.

Sakurai, T., \& Reardon, T. (1997). Potential demand for drought insurance in burkina faso and its determinants. American Journal of Agricultural Economics, 79(4), 1193-1207.

Serigati, F., Rodrigues, R. M., Possamai, R., \& Vieira Filho, J. E. R. (2017). O mercado de trabalho na fronteira do agronegócio: quanto a dinâmica no Matopiba difere das regiões mais tradicionais?. Brasília: Ipea. Retrieved from https://www.ipea.gov.br/portal/index.php?option=com_content\&view=article\&id=29810

Siddiqui, S. A., \& Das, S. (2017). Life insurance: challenges and opportunities in rural India. International Journal of Advanced Research, 5(8), 867-874.

Silva, J. A. Da., Teixeira, M. S. G., \& Santos, V. G. D. (2014). Avaliação do Programa de Subvenção do Prêmio do Seguro Rural-2005 a 2012. Revista de Política Agrícola, 23(1). Retrieved from https://seer.sede.embrapa.br/index.php/RPA/article/view/892

Stiglitz, J. E., \& Walsh, C. E. (2003). Introdução à macroeconomia. Rio de Janeiro: Campus.

Tabosa, F. J. S., \& Oliveira, D. V. (2019). Avaliação do Seguro Agrícola na Produtividade. In J. E. R. Vieira Filho, \& A. C. P. Vieira (Eds.), Diagnóstico e desafios da agricultura brasileira (pp. 189-206). Retrieved from https://dea.ufc.br/wp-content/uploads/2019/11/diagnostico-e-desafios-da-agricultura-brasileira.pdf

Tabosa, F. J. S., \& Viera Filho, J. E. R. (2018). Programa De Subvenção Ao Prêmio Do Seguro Rural (Psr): Avaliação De Impacto Na Área Plantada E Na Produtividade Agrícola No Brasil. In A. Sachsida (Ed.), Políticas públicas: avaliando mais de meio trilhão de reais em gastos públicos (Vol. 1, pp. 225-246 ). Brasília: Ipea.

Traoré, M. (2018). Government Spending and Inclusive Growth in Sub-Saharan Africa: a Panel VAR Analysis. Études et Documents Working Paper Series.N. 15. Cerdi.

Vieira Filho, J. E. R., \& Fishlow, A. (2017). Agricultura e indústria no Brasil: inovação e competitividade (p. 305). Brasília: IPEA. Retrieved

from https://www.ipea.gov.br/portal/index.php?option=com_content\&view=article\&id=29768

Vieira Filho, J. E. R., \& Gasques, J. G. (2016). Agricultura, transformação produtiva e sustentabilidade (pp. 143-164). Brasília: Ipea. Retrieved from https://www.ipea.gov.br/portal/index.php?option=com_content\&view=article\&id=28219 
Walker, T. S., \& Jodha, N. S. (1986). How small farm households adapt to risk (pp. 17-34). Crop insurance for agricultural development.

Webb, P., \& Von Braun, V. (1994). Famine and food security in Ethiopia: Lessons for Africa. Chichester, New York: John Wiley.

Ying, Y. H., \& Chang, K. (2019). The effect of National Health Insurance on private health expenditure in Taiwan: crowd in or crowd out?. Journal of the Asia Pacific Economy, 25(2), 371-385. https://doi.org/10.1080/13547860.2019.1665327

\section{Notes}

Note 1. To understand the evolution of the dynamics of Brazilian agriculture in a broad way, we suggest the works of Buainain et al. (2014), Campos and Navarro (2013), Gasques et al. (2010), Gasques et al. (2012), Vieira Filho and Gasques (2016) and Vieira Filho and Fishlow (2017).

Note 2. However, Ozaki (2008) points out that there are obstacles that inhibit leverage, such as problems related to information asymmetry (moral risk) and the absence of adequate pricing methodology.

Note 3. The North and Northeast regions together feature less than $10 \%$ of insured producers and insurance policies acquired in Brazil. For more details, see Tabosa and Vieira Filho (2018).

Note 4. It should be observed that, as analyzed by Serigati et al. (2017), modern agriculture is not labor intensive. When analyzing the expansion of the new agricultural frontier in Brazil, such as the MATOPIBA region (Maranhão, Tocantins, Piauí and Bahia), the employment data show that, as there is an increase in production in this region, there is a decrease in jobs in the sector's primary activity. However, it should be noted that the jobs generated in this type of agriculture are accompanied by better remuneration and higher legal quality.

Note 5. The municipalities that make up the sample are: Palmeirante / TO, Guaraí / TO, Rio dos Bois / TO, Porto Nacional / TO, Baixa Grande do Ribeiro / PI, Santa Filomena / PI, Uruçui / PI, Barreiras / BA, Formosa do Rio Preto / BA, Luiz Eduardo Magalhães / BA, Riachão das Neves / BA, São Desidério / BA, Correntina / BA, Jaborandi / BA, Grajaú / MA, Alto Parnaíba / MA, Balsas / MA, Tasso Fragoso / MA and Loreto / MA ; totaling 19 municipalities in the MATOPIBA region.

Note 6. For more information on VAR models and the panel VAR model variation, we suggest reading Canova and Cicarelli (2013) for a comprehensive survey.

Note 7. The confidence intervals for the impulse-response functions were defined using the bootstrap method proposed by Hall (1992).

Note 8. Formosa do Rio Preto is the largest municipality in Bahia. The municipality is the largest soy producer in Bahia and the fifth largest national. In addition, it is the largest cotton producer in Bahia, the tenth largest producer of corn in Bahia (IBGE, 2020).

Note 9. São Desidério stands out as one of the most competitive municipalities in the agricultural sector in Brazil. In 2012, it obtained the highest production value in the country. In 2013, it was identified as the largest agricultural GDP in the country, with a turnover of R $\$ 2.285$ billion (IBGE, 2020).

Note 10. Mais detalhes ver Tabosa e Vieira Filho (2018).

Note 11. For more details, see Barbosa Filho (2017).

Note 12. For more details, see IBGE (2020).

\section{Copyrights}

Copyright for this article is retained by the author(s), with first publication rights granted to the journal.

This is an open-access article distributed under the terms and conditions of the Creative Commons Attribution license (http://creativecommons.org/licenses/by/4.0/). 